Louisiana State University

LSU Digital Commons

Faculty Publications

Department of Geography \& Anthropology

2010

\title{
Renegotiating Barbuda's commons: recent changes in Barbudan open-range cattle herding
}

Andrew Sluyter

Louisiana State University, asluyter@lsu.edu

Amy E. Potter

Follow this and additional works at: http://digitalcommons.lsu.edu/geoanth_pubs

\section{Recommended Citation}

Sluyter, Andrew and Potter, Amy E., "Renegotiating Barbuda's commons: recent changes in Barbudan open-range cattle herding" (2010). Faculty Publications. 24.

http://digitalcommons.lsu.edu/geoanth_pubs/24

This Article is brought to you for free and open access by the Department of Geography \& Anthropology at LSU Digital Commons. It has been accepted for inclusion in Faculty Publications by an authorized administrator of LSU Digital Commons. For more information, please contact gcoste1@lsu.edu. 


\title{
Renegotiating Barbuda's commons: recent changes in Barbudan open-range cattle herding
}

\author{
Amy E. Potter* and Andrew Sluyter*
}

Department of Geography and Anthropology, Louisiana State University, LA, USA

\begin{abstract}
Barbuda remains little developed and sparsely populated relative to its neighbors in the Leeward Lesser Antilles, a rather extraordinary and relatively unknown Caribbean place. Much of its distinctiveness derives from the communal land-tenure system, itself rooted in three centuries of open-range cattle herding. Yet, as revealed through interviews, newspaper archives, and landscape observations, openrange cattle herding has declined over the past three decades, with related changes in land tenure. As the new Barbuda Land Act came into effect in 2008 , codifying the communal tenure system, the very landscape elements that manifest open-range herding have become obscure. In particular, the rock-walled stockwells have become largely defunct, many of the walls lie in ruins or have been entirely consumed by the crusher that converted them into gravel to surface roads. With the principal land use that had supported communal control largely out of practice, usufruct access to land now largely obsolete, the new act might have little actual impact in preserving Barbuda's uniqueness.
\end{abstract}

Keywords: Caribbean; Antigua and Barbuda; land tenure; land use

\section{Unknown Barbuda}

Barbuda is often hailed by its residents as one of the Caribbean's last remaining unspoiled islands (Kincaid 1988). Located in the Leeward Lesser Antilles of the Caribbean, the island remains little developed and sparsely populated relative to its neighbors (Figure 1). A comparison with Antigua, the other part of the country of Antigua and Barbuda, as well as with many of the other nearby islands, such as St. Kitts or St. Martin, illustrates Barbuda's anomalous character. Antigua has a population of some 75,561 on 108 square miles, for a density of 700 people per square mile; in comparison, a mere 1,325 people live on Barbuda's 62 square miles, for a density of 21 people per square mile (SDMFE 2004). Satellite imagery

\footnotetext{
*Amy E. Potter is a Ph.D. candidate at the Department of Geography and Anthropology, Louisiana State University, Baton Rouge, LA, USA. Email: apotte2@1su.edu; Andrew Sluyter is an Associate Professor at the Department of Geography and Anthropology, Louisiana State University, Baton Rouge, LA, USA. Email: asluyter@1su.edu.
} 


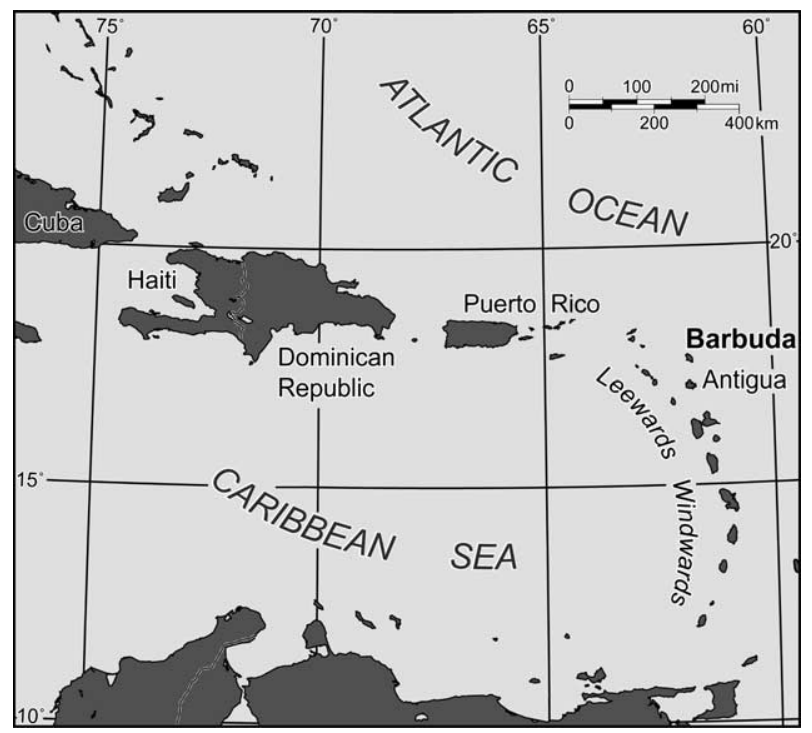

Figure 1. Location map of Barbuda in the Leeward Lesser Antilles of the Caribbean. Source: Online Map Creation www.aquarius.geomar.de. Cartography by Andrew Sluyter.

reveals Antigua's commensurate lack of vegetative cover relative to Barbuda's, the latter's broken by little more than the single village of Codrington and the main road connecting the Caribbean and Atlantic coasts (GEDG 2005). Many additional characteristics render Barbuda a rather extraordinary and relatively unknown Caribbean place.

Despite that general anonymity, over the past half-century quite a number of geographers as well as a few anthropologists and historians have studied various aspects of Barbudan land and life (Harris 1965; Russell and McIntire 1966; Berleant-Schiller 1974, 1977a, 1977b, 1983, 1984, 1991; Watters 1980; Tweedy 1981; Lowenthal and Clarke 1977, 2007; Nicholson 1991). The focus of recent publications on Barbuda detailing cattle herding follows a rich tradition in geography (Jordan 1993 and Sluyter 2009). Much of the research on the island has focused on the land-tenure system, one based on usufruct rights to communal property. Unlike the so-called family lands that emerged in many parts of the Caribbean during emancipation in the nineteenth century, in which the descendants of the owner of a single small plot inherit in perpetuity the right to use that land in common, the entire community of Barbudans claims common ownership of and usufruct rights to their entire island (Olwig 1999). Barbudan communal land tenure thus provides yet another contrast with the private and public lands of Antigua, derived from that island's colonial history of sugar estates and Crown lands. The previous research on Barbuda has established how a regionally distinct system of land tenure emerged during the twentieth 
century out of Barbudans' strong sense of place and community identity as well as out of the island's land-use history, mainly emphasizing the impact of three centuries of open-range cattle herding (Berleant-Schiller 1974; Tweedy 1981). Some have even held Barbuda up as a "Triumph of the Commons," an empirical rebuttal to Garrett Hardin's well-known theory about "the Tragedy of the Commons", in which common pastures inevitably suffer degradation (Hardin 1968; Lowenthal and Clarke 2007).

Barbuda's recent changes in its use of communal lands position it as an important case study in a vast array of literature trying to understand the sustainability of these tenure systems and often their collapse under the pressure to privatize (McCay and Acheson 1987; Feeny et al. 1990; Bromley 1992; Kay 1997; Hardin 1998; Sserunkuuma and Olson 2001; Kishigami and Savelle 2005; Perramond 2008). Since the emergence of Hardin's controversial essay, scholars have studied an assortment of resources that fall under common property regimes, which include agricultural lands, pastures, rangelands, and marine resources (Fuys et al. 2005).

Case studies like this one, focusing on Barbuda, inform our understanding of changing land tenure processes around the world. Katherine Verdery, in her study of shifting land tenure in post-socialist Romania argues, "There is no global process of privatization, only specific instances of it, and that following any instance provides insight into how the abstract idea of privatization might occur ... There is no typical village - all have their peculiarities... It is precisely in the local settings that we see how people negotiated their way through the tremendous challenge [set before them]" (Verdery 2003, p. 30). Of particular relevance to Barbuda, with the propensity for its population to migrate, are recent publications exploring the effects of migration and land use (Byron 2007; Mills 2007; Mutersbaugh 2002). Some scholars, in exploring these complex connections, have found that migration has led to agricultural abandonment due to labor loss, which has ultimately led to a decline in cultivation (Black 1993). Other scholars conclude that rather than resulting in agricultural decline, remittances from abroad were used for agricultural improvements (Durand and Massey 1992; Jokish 2002).

Barbuda sheds light on how uses of and attitudes toward communal lands by local peoples are changing under the onslaught of globalization and neoliberal policies. Fieldwork during the summers of 2007 and 2008, however, reveals just how profoundly Barbuda has changed since the preceding research, most of it dating from the 1960s through the 1980s. In particular, interviews, newspaper archives, and landscape observations reveal the recent decline of open-range cattle herding, the reasons for it, and its relationship to emerging changes in the system of communal land tenure that embody the profound transformation of this extraordinary place. The case study of Barbuda illustrates how landscape does not passively change in response to alterations in land 
tenure and other social dynamics. Instead, landscape transformations actively feedback into the process of change to either counter or reinforce it (Sluyter 2003).

\section{Origins of Open Range and Communal Lands}

Precisely when cattle and other livestock first reached Barbuda remains unclear. The Spaniards attempted colonization of the Leewards during the 1520s, possibly including Barbuda (Watts 1987). The Spaniards, prior to expulsion by the Caribs, might have followed their usual practice of introducing various livestock (Sauer 1966; Crosby 1972). A series of British occupations beginning in the late 1620 s, intermittent at first but becoming effectively continuous in 1666, certainly must have introduced large stock because by 1676 the island had a reputation for herds of cattle and horses (Harris 1965).

Open-range cattle herding became Barbuda's chief use as an English colony. Between 1668 and 1898 the Crown leased out the entire island, with the Codrington family as leaseholder from 1685 through 1870 (Tweedy 1981; Nicholson 1991). The Codringtons' repeated attempts to establish plantations for cotton and other crops failed, in part due to the shallow soils, an average annual rainfall of only 35.4 inches, a long winter dry season, frequent droughts, and a paucity of surface water. Attempts to raise cattle in enclosed pastures failed for the same reasons: the soils and precipitation could not sustain enough fodder within a paddock to support a herd throughout the year (Sluyter 2009). In contrast, openrange cattle herding thrived by allowing the stock to graze and browse vegetation throughout the island: mostly a xerophytic, open evergreen shrubland that includes succulents, thorny invasives such as acacia, and some grassy openings (Harris 1965; Francis et al. 1994). During the wet season, teams of Codrington slaves hunted down the untended, feral cattle on the open range. During the dry season, though, as surface water progressively dried up, the herders trapped cattle that came to drink at a series of rock-walled wells established around the village (Figure 2). In addition to the rock walls enclosing those stockwells, another kept livestock out of Codrington and a few others protected the alwaysfaltering agricultural fields. That general lack of land enclosure and private property during colonial times helped to ensure that the open range persisted through emancipation in 1834, termination of the last lease in 1898, and subsequent direct management by the Colonial Office (Hall 1971).

Upon associated statehood in 1969 and independence as part of the country of Antigua and Barbuda in 1981, Barbudans argued that the island had become their communal property rather than public lands, a position both supported by and supportive of the continuation of openrange herding (Coram 1993; Lowenthal and Clarke 2007; Sluyter 2009). 




Figure 2. Map of Barbuda showing rock-walled stockwells, village wall, and other relevant landscape elements circa 1968. Sources: USAF 1958; DOS 1970; June 2007 Field Book, sketches and maps. Cartography by Andrew Sluyter.

Barbudans certainly took over and divided the cattle herd, branding individual head as private property and selling the meat mainly on Antigua. But they continued to rely on hunting the cattle on an open range and trapping them at the walled wells. With cattle privately owned and more profitable than farming or fishing but reliant on open range, Barbudans had great incentive to resist land privatization and enclosure. And they have been largely successful in that effort, with most of the island remaining unfenced and under communal control. 
As late as the 1980s, several crews of cattle runners hunted and trapped the small, short-horned cattle (Berleant-Schiller 1974, 1977b; Sluyter 2009). The crews typically numbered four to six men who at any time of year would chase a herd on horseback until a cow or bull tired enough to be cut out and brought down with dogs, by a cattle runner on foot with a lasso, with a flying leap from horseback to wrestle the animal to the ground, similar to the bulldogging event of North American rodeos or with a tail twisting technique similar to the Mexican coleadero and the Venezuelan coleo.

During the dry season, the crews would post watch at night at the rock-walled stockwells (Figure 3). The wells themselves consisted of a coaming of mortared limestone blocks some $4 \mathrm{~m}$ in diameter and $0.75 \mathrm{~m}$ high, with the water table $2-3 \mathrm{~m}$ below ground level ${ }^{1}$ (Sluyter 2009). Of identical construction as the coamings and built into their sides, the drinking troughs measured about $9 \mathrm{~m}$ long, $1.5 \mathrm{~m}$ wide, and $0.7 \mathrm{~m}$ high. Some of the wells had additional drinking pans, similar to but lower and smaller than the troughs, for small stock. The troughs and pans rested directly on the coral limestone bedrock that, except for occasional patches of soil, floored the enclosures. Herders raised water to the surface with a bucket attached by rope to a windlass. The walls that enclosed the wells had a width of $0.75-1 \mathrm{~m}$ and a height of $2-2.5 \mathrm{~m}$. Most of the enclosures consisted of dry-laid inner and outer walls cored with smaller rocks. Near entrances and corners solid walls, sometimes mortared, provided greater strength. Rather than continuous upper courses, the highest walls consisted of double wooden rails set into rock pillars. A continuous ledge about $0.5 \mathrm{~m}$ high or, in some cases, a series of discontinuous steps ran around the bases of many of the walls. An opening of some $3 \mathrm{~m}$ width gave entry to the main enclosure, with a narrower opening leading into a

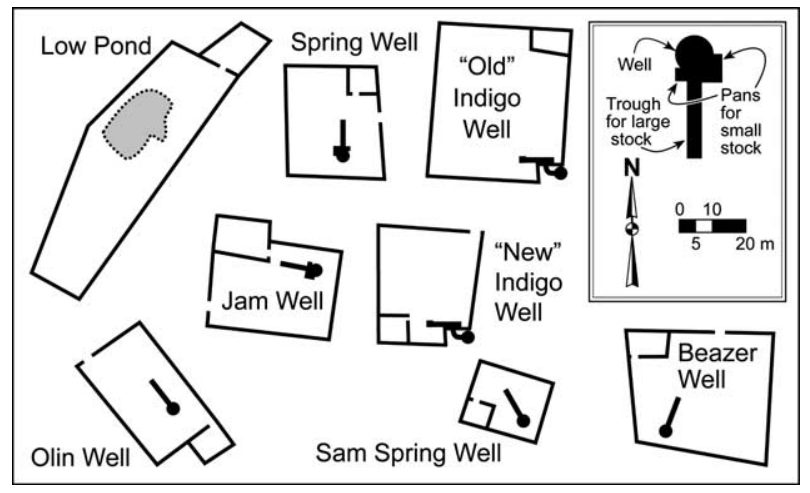

Figure 3. Plans of known rock-walled stockwells; note that Indigo Well had a larger enclosure before reconstruction in the 1970s, hence the "Old" and "New" Indigo Wells. Sources: USAF 1958; June 2007 Field Book, sketches and maps. Drafting by Andrew Sluyter. 
smaller "catching pen" typically built into a corner of the main enclosure (Sluyter 2009). The main enclosures averaged $1,211 \mathrm{~m}^{2}$ and the catching pens $107 \mathrm{~m}^{2}$ (USAF 1958; Sluyter 2009). Iron hinge pins mortared into the sides of the openings supported double gates of wooden pickets.

When cattle entered the main enclosure to drink at the trough, the cattle runners would shut the main gate and chase the animals into the catching pen. Once all the stock had entered the catching pen, the crew shut its gate and reopened the main one so that more cattle could enter. When enough cattle had accumulated inside the catching pen, cattle runners subdued them with tail twisting, lassoing from atop the walls, or bulldogging. Anytime a bull would turn on a cattle runner, one of the steps built into the base of the walls would provide an escape route. The cattle runners then tied the much subdued cattle together in a line to lead them to Codrington, with half the crew holding the rope ahead of the column and the other half behind.

Barbudans of that generation considered cattle running a prestigious occupation, not least because it earned the crews a substantial income (Berleant-Schiller 1974). A calf in the early 1970s had a value of \$70 XCD (Eastern Caribbean Dollars), a breeding cow $\$ 150 \mathrm{XCD}$, and a bull from $\$ 150$ to $\$ 230$ XCD depending on size, which could range from a small $180 \mathrm{~kg}$ to an even smaller $113 \mathrm{~kg}$ (Berleant-Schiller 1974). The cattle runners were aged between 25 and 45 , and they both owned cattle themselves and herded for other owners, from the many with small herds of half a dozen head to the few "cattle barons" with a hundred or so. When catching cattle for other owners, the crews earned about \$30 XCD per head. Brands and ear marks established ownership, and the beef provided cash income through live exports to Antigua as well as feeding Barbudans with fresh and salt-cured beef.

In general, that herding ecology had persisted since at least the eighteenth century and perhaps as early as the seventeenth, as revealed in some detail in the published accounts of travelers who visited Barbuda during colonial times as well in the extensive Codrington Papers held by the National Archives of Antigua and Barbuda (Tweedy 1981; Sluyter 2009). The main changes since Codrington times involved the replacement of slaves with nominally free labor in the nineteenth century followed in the twentieth century by the replacement of a monopoly leasehold of land and ownership of livestock with communal land tenure and multiple cattle owners.

Open-range cattle herding began to decline in the 1980s, however, quite precipitously considering how it had dominated Barbudan land use for the preceding three centuries. Some 2,000 feral cattle as well as additional horses, sheep, goats, donkeys, wild pigs, and deer still range freely throughout most of the island. But few Barbudans now run cattle, and the enclosed wells suffer great disrepair (Figure 4). Moreover, the decline of open-range cattle herding relates to ongoing changes in the 

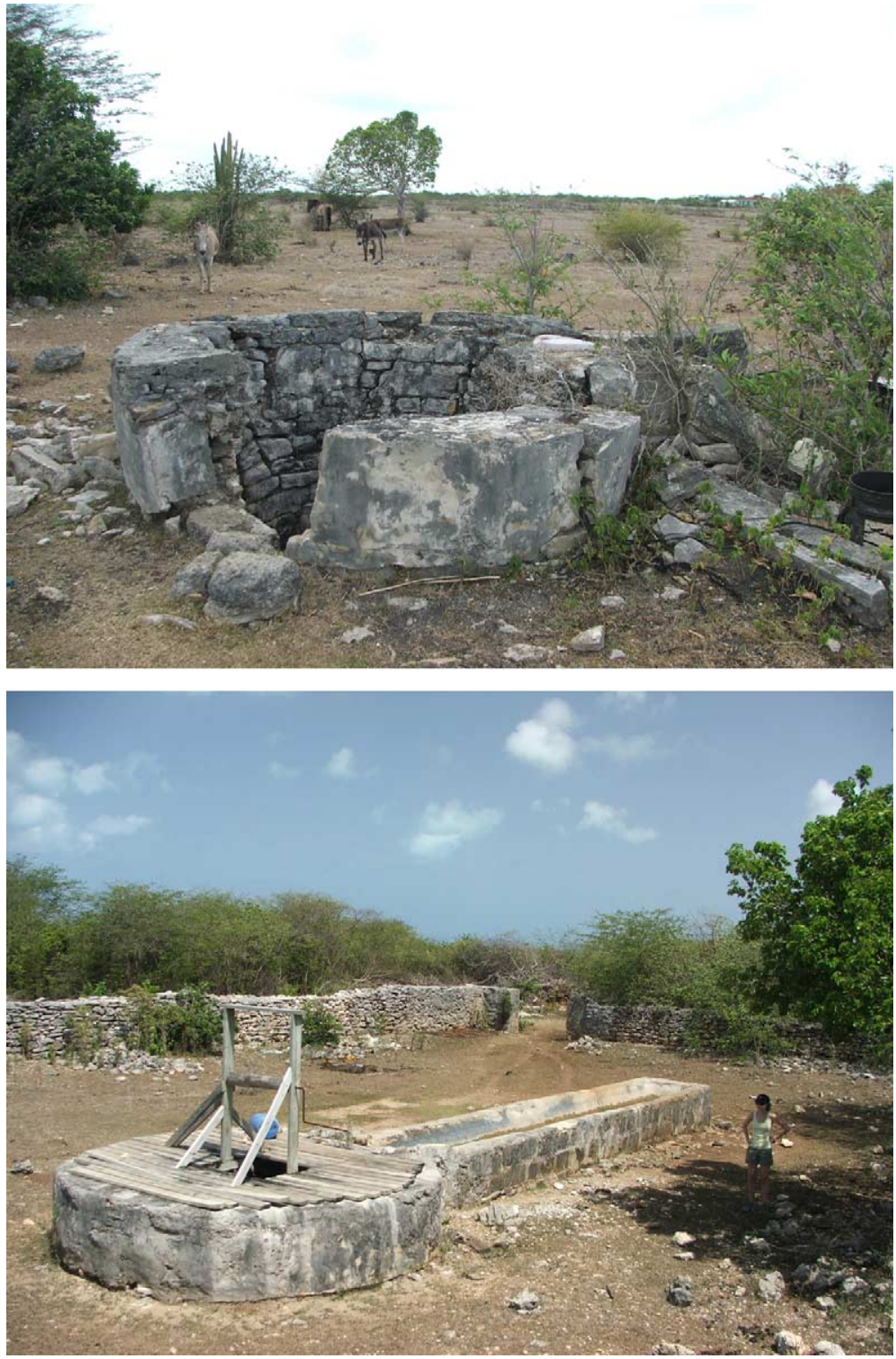

Figure 4. Top: Spring Well, the stockwell in worst repair, suffers a split coaming and retains only vestiges of the rock walls that once enclosed it. Bottom: Olin Well, one of the stockwells in best repair and the only one to retain a bucket. Photography by Andrew Sluyter, June 2007.

system of communal land tenure, another longstanding characteristic of Barbuda as a place and Barbudans as a people. Since the preceding research on Barbuda predates that decline, the existing literature neither 
describes its character, explains it, nor relates it to on-going changes in the system of communal property.

\section{Character of the Decline of Cattle Herding}

Only a single crew of three cattle runners continues to hunt cattle, largely as a diversion from their jobs and to earn extra cash. The cattle hunts typically begin Friday at midnight in order to sell the meat Saturday morning for family barbeques on Barbuda or, given a large enough animal, on the hoof to a butcher on Antigua. The crew chases the cattle on horseback until a large cow or bull tires enough that either they can bring it down with bulldogging and tail twisting or the pit bulls can corner it and latch their teeth in its face and neck to bring it to its knees. The cattle runners then tie a rope around the horns to lead the animal back to Codrington for slaughter.

Since feral cattle occur in such abundance relative to the demand for beef, branding no longer occurs. Instead, the feral herds have become common property that the single crew of avocational cattle runners hunt for themselves or on commission for other Barbudans. Commercial beef production has instead come to focus on small herds of relatively recently introduced zebu crosses, tame in contrast to the feral stock, tethered while grazing, owned as private property, and paddocked at night to prevent loss. The owners sell them to butchers on Antigua and some of the meat, once processed and chilled or frozen, comes back to Barbuda for sale.

The current cattle runners no longer use the rock-walled stockwells to trap cattle (Sluyter 2009). All but Olin Well lack even buckets to draw water. Four wells have largely intact walls: Indigo, Jam, Beazer, and Olin. The other two, Spring Well and Sam Spring Well, retain only the barest remnants of such walls. Spring Well also suffers a partially collapsed coaming and a trough that no longer holds water. None of the surviving enclosures have a functioning gate except Indigo Well, and it only to the main enclosure, not the catching pen. A rock wall also surrounds Low Pond, a natural water hole, but lacks gates to both the main enclosure and catching pen. Those stockwells remain communal property, though, designated as historic sites and with efforts underway to preserve, if not quite restore them.

\section{Reasons for the Decline of Cattle Herding}

The reasons for the recent decline of open-range cattle herding, relatively precipitously considering how it dominated the land use and character of Barbuda for some 300 years, are multifaceted and complex. The economic processes involved seem clearest, but they in turn relate to cultural, social, political, and environmental ones. Moreover, understanding the spatially 
differentiated landscape impacts involved requires analysis of the relationships among the various types of processes.

In terms of economic processes, the dwindling demand for the island's cattle during the 1980s discouraged herding. Demand decreased because of changes in what had been the main market for nearly three centuries: Antigua. As the Antiguan sugar industry mechanized and eventually collapsed after emancipation in 1834, the demand for Barbudan oxen declined (Sluyter 2009). In parallel, synthetic materials increasingly replaced cattle products such as leather, tallow, and bone char over the 1900s. Antiguans also came to prefer foreign over Barbudan beef, which had a peculiar flavor because the cattle mainly subsisted by browsing leaves rather than grazing (Sluyter 2009). During the colonial period, the main Antiguan consumers had been slaves on sugar plantations and sailors stationed at the Royal Navy's dockyard at English Harbour, neither of which had much dietary choice. Even with emancipation, poverty maintained demand for cheap Barbudan beef. As the expansion of the Caribbean tourism economy reached Antigua in the 1980s, however, more consumers began to choose foreign beef over Barbudan beef (Coram 1993). Even now Barbudans consume more foreign than Barbudan beef and dairy products. Because of the consequent lack of meat processing facilities on Barbuda, even the few tame cattle that Barbudans raise must first go to Antigua for slaughter before returning for sale in Codrington.

At the same time as the market for Barbudan open-range cattle largely disappeared, opportunities for wage labor on the island began to expand. Building of the first luxury hotel, the Coco Point Lodge, on the south coast during the 1960s provided construction jobs and, thereafter, steady employment during the winter tourist season. The K-Club and The Beach House, also on the south coast, followed with more seasonal employment. In addition, since 1975 a succession of foreign companies has quarried sand at Palmetto Point for use in resort construction projects throughout the Caribbean (Coram 1993; Albuquerque and McElroy 1995). Those sand exports have resulted in jobs for Barbudans, royalties for the federal and local governments, and detrimental environmental impacts such as groundwater contamination (Campbell 2006). The Barbuda Council, the locally elected body established in 1976 during the period of associated statehood, uses some of the sand royalties to employ an estimated 400 workers at an average salary of $\$ 17,000 \mathrm{XCD}$, equivalent to $\$ 6,513 \mathrm{USD}$. That rather large civil service, about a third of the population, includes jobs ranging from blue- to white-collar work.

Remittances from Barbudans living abroad have become another major source of income. By some estimates, three times as many Barbudans live in New York City as on Barbuda, with additional expatriate communities in other parts of the United States such as the Virgin Islands, the United Kingdom and Canada (Coram 1993, 1989). 
The history of the Barbudan diaspora parallels the overall pattern of the British West Indies, a regional migration to other Caribbean islands beginning after emancipation and then an expansion to the US, UK, and Canada after World War II (Gmelch 1992). No comprehensive statistics exist on either the numbers of Barbudans living abroad or on the amount of money they remit to the island, but a census dating to 1971 revealed that more than half of the households received some form of support from abroad, including cash or gifts sent by relatives in New York City or elsewhere, pension or social security checks, and wages from seasonal employment abroad (Riva Berleant-Schiller Papers, National Anthropological Archives, Smithsonian Institution, Washington, DC, accession no. 2005-1 [hereafter, RBS Papers]). Remittances and seasonal migratory employment abroad certainly continue and might have grown.

Such economic processes relate to cultural ones, especially the negative memories associated with wells and other aspects of the colonial landscape built by the enslaved ancestors of Barbudans. The Barbuda Voice, a newspaper published in New York City between 1969 and 1990 but read by Barbudans everywhere, illustrates some of those negative associations.

The government should consider that Barbudans are still drawing water from wells for their domestic needs.... It is time enough for Barbudans to stop going to wells to draw water. Not much has been done to improve the ancient water system. Not much has been done to improve Barbuda. To many Barbudans, the 'Village Well' is a glaring monument to a forsaken island (R. John 1970b, p. 8).

When in 1833, with slavery no longer a money making business, you were left on your own, but because neither you nor the Island were considered 'Important', both were soon forgotten. Forgotten as to adequate schooling, forgotten as to any means of industry for self-improvement, forgotten as to a Hospital for births or severe illness, forgotten as to any real benefits, as a people, under the old colonial or new Federated systems (J. John 1970a, p. 8).

Cattle running certainly remained a prestigious occupation as one of the leading sources of income on the island, but as demand for Barbudan cattle dwindled and wage employment opportunities expanded the associations between slavery, herding, and wells might have contributed to the decline.

Barbudans also attribute the general decline in such manual labor to processes that have changed the social expectations of the younger generation. Adult interviewees typically believe that adolescent Barbudans devalue rural labor, including cattle running, and to some degree manual labor in general. Yet Berleant-Schiller encountered the same 
opinions as early as 1971 and also found that adolescents, now the adults among our interviewees, regarded the cultivation of land as an unpleasant necessity, bearable only as long as no other source of income was available (RBS Papers). Moreover, currently, three young men have chosen to become avocational cattle runners because they enjoy hunting, riding, horses, and dogs as a diversion from their jobs. Other young Barbudans work in fishing and lobster diving, which can earn as much as $\$ 1,000$ XCD per week.

Political processes, both local and national, also relate to the decline. During the 1970s, determination of calf ownership involved a political process of negotiation among alliances of herd owners and cattle runners (Berleant-Schiller 1977b; Sluyter 2009). During the 1980s, according to one interviewee, the owner of the largest herd began to claim absolutely every unbranded calf. Although the details remain unclear, such unequal social relations seem to have discouraged the owners of smaller herds from continuing cattle production and eventually contributed to its decline. Enduring antipathy between the local and national governments precluded legal formalization of cattle ownership and reestablishment of a balance of power among the herd owners and several crews of cattle runners.

National political relations, between Barbuda and the central government, thus also pertained to the decline. Beginning with associated statehood in 1969 and accelerating with independence in 1981, the national government has attempted to assert control over Barbuda, converting what it views as public lands into private property or long-term leases. One scheme offered Barbudans title deeds to house lots outside of the former village wall as a prelude to more general land sales (BerleantSchiller 1986). The Barbuda Voice preserves the vociferous opposition among those suspicious of the motivation.

I understand the new Government is planning to give deeds to the people for their land.... If Barbuda [sic] people accept deeds for their land the Government will sell Barbuda piece by piece and who don't have land at the time would have to buy land from then on .... So anyone that comes to you with this story about giving deeds, he is planning to take away our privileges of having access to free land and is going to sell out Barbuda to help build Antigua (Punter 1970).

A more direct approach involved unilateral deals with foreign developers, such as the potential 1971 sale by the national government of a quarter of Barbuda to a foreign resort developer, also opposed by Barbudans.

This option on one quarter of the Island, was to be given to his company by the Antiguan Government in return for $20 \%$ of the Companies [sic] profits. Only $5 \%$ was to be given to a 'Citizens of Barbuda Trust Fund' (R. John 1970c, 9 italics in original). 
Barbudans generally resisted such attempts to end communal land tenure even though the land uses that had once mutually supported it, mainly open-range herding but also shifting cultivation and charcoal burning, were in decline. In 1980, the contingent that represented Barbuda at the independence negotiations in London used the heritage of communal land tenure as the major argument to advocate, unsuccessfully, for either independence apart from Antigua or for remaining a British colony (Coram 1993; Lowenthal and Clark 2007). While unsuccessful in that attempt, Barbudans have nonetheless been able to resist the national government's attempts to end communal land tenure on Barbuda.

While all the foregoing processes pertain to the decline, their spatially differentiated impact on the Barbudan landscape depended on and fed back on their relationships with each other and with parallel processes, such as population growth, hurricane damage to housing, and increasing automobile ownership. During most of the colonial period, a limestone wall measuring 1.2 meters high and half a meter thick had enclosed the village of Codrington and virtually all Barbudans lived within it (Figure 5). During the colonial period, that wall both kept livestock out of the village and kept villagers in, the purpose of the Codringtons being to monopolize the use of land and resources beyond the village (Lowenthal and Clarke 2007; Sluyter 2009). As Barbudans gained more control over the island in the twentieth century, they began to remove the wall and expand the village, first southward and then eastward (Figure 6). Several major factors encouraged households to move out of the core village, including widespread damage to houses during hurricanes Donna in 1960 and Luis in 1995, and population growth-from 492 in 1832 to 1,325 in 2001 (Lowenthal and Clarke 1977; Tweedy 1981, 208; Lawrence 1996; SDMFE 2004). Other factors attracted people to the new suburbs: piped water reduced reliance on the village well; more funds - whether derived from remittances, migratory employment, the pensions of returned retirees, or wage labor at the hotels or sand quarry - became available to purchase construction materials, loans being uncommon because of the lack of title to serve as collateral; and the increased number of cars, from 15 in 1977 to 220 in 2008, reduced incentives to keep the village compact (Berleant-Schiller 1991). As a result, more families built new houses beyond the former wall, and more derelict houses came to mark the colonial core (Figure 7). The village wall itself provided a ready source of limestone blocks to crush into gravel for road and airstrip construction (Watters 1980).

In turn, the expansion of the village into the zone of stockwells negatively impacted the herding system, ending the practice of trapping cattle during the dry season. Most basically, construction activity made the feral cattle too wary to drink at the wells. Some residents of the new suburbs even shot at the cattle to discourage their use of the wells. Many Barbudans, in fact, now consider not only cattle but donkeys and horses a 



Figure 5. Top: remnants of the village wall at the intersection of Lagoon Drive and Low Mission Street. Bottom: the rock crusher, now abandoned, that turned many of the walls into gravel for road and airstrip construction. Photography by Amy E. Potter, June 2008.

nuisance because of their feces, or "mess." Also, the low demand for abundant cattle makes cattle hunting much more productive than trapping, which would require maintaining the wells. As use of the wells declined along with the number of cattle runners, they initially decreased 


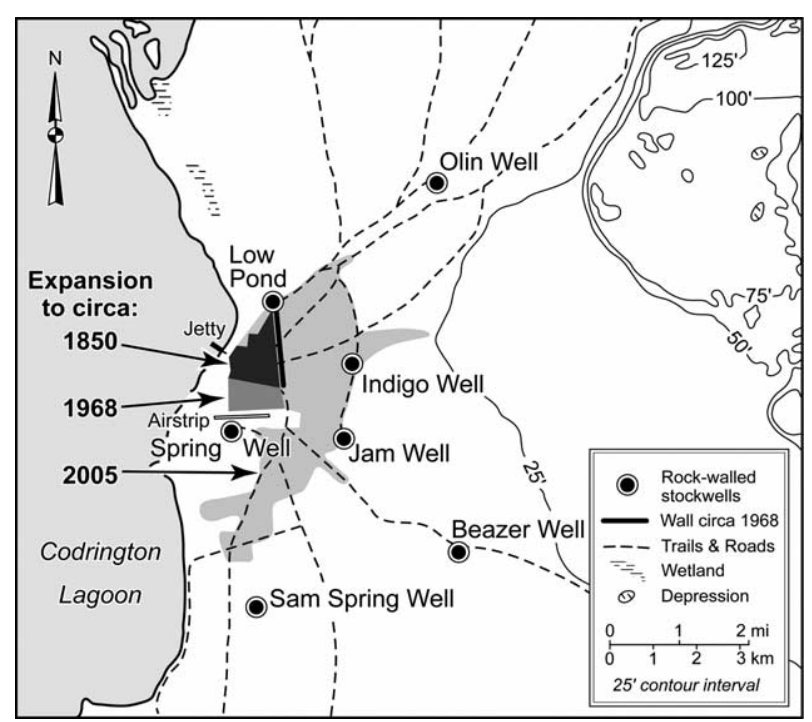

Figure 6. Expansion of Codrington to circa 1850, 1968, and 2005 in relation to the rock-walled stockwells. Sources: USAF 1958; DOS 1970; GEDG 2005; Barbuda 2007; June 2007 Field Book, sketches and maps. Cartography by Andrew Sluyter.

the size of the enclosure at Indigo Well, one of the wells closest to the village, and eventually stopped using all but Olin Well, one of the wells furthest from the village (USAF 1958). The walls around Spring Well and Sam Spring Well then joined the Village Wall in the stone crusher, and now even at Olin Well the gate lays on the ground beside the entrance.

The decline of the open-range system of cattle hunting and trapping thus involved a positive feedback operating through landscape transformations. As the processes through which herding declined also resulted in village expansion, the trap wells engulfed by the new suburbs became unusable and further precipitated the decline. The cattle running now practiced by the single crew therefore bears only superficial resemblance to that of the twentieth century. Not only has the decline vastly reduced the scale of open-range cattle herding on Barbuda, but it has fundamentally changed the herding ecology. The rock-walled wells, an element of the open-range herding system that made Barbuda such a unique place, now persist only as "historic wells," a designation created by the Barbuda Council (Barbuda 2007).

\section{Relationship to Changes in the Common Property System}

The system of communal land tenure that emerged on Barbuda during the twentieth century has no clear legal basis (Coram 1993). The Antigua 

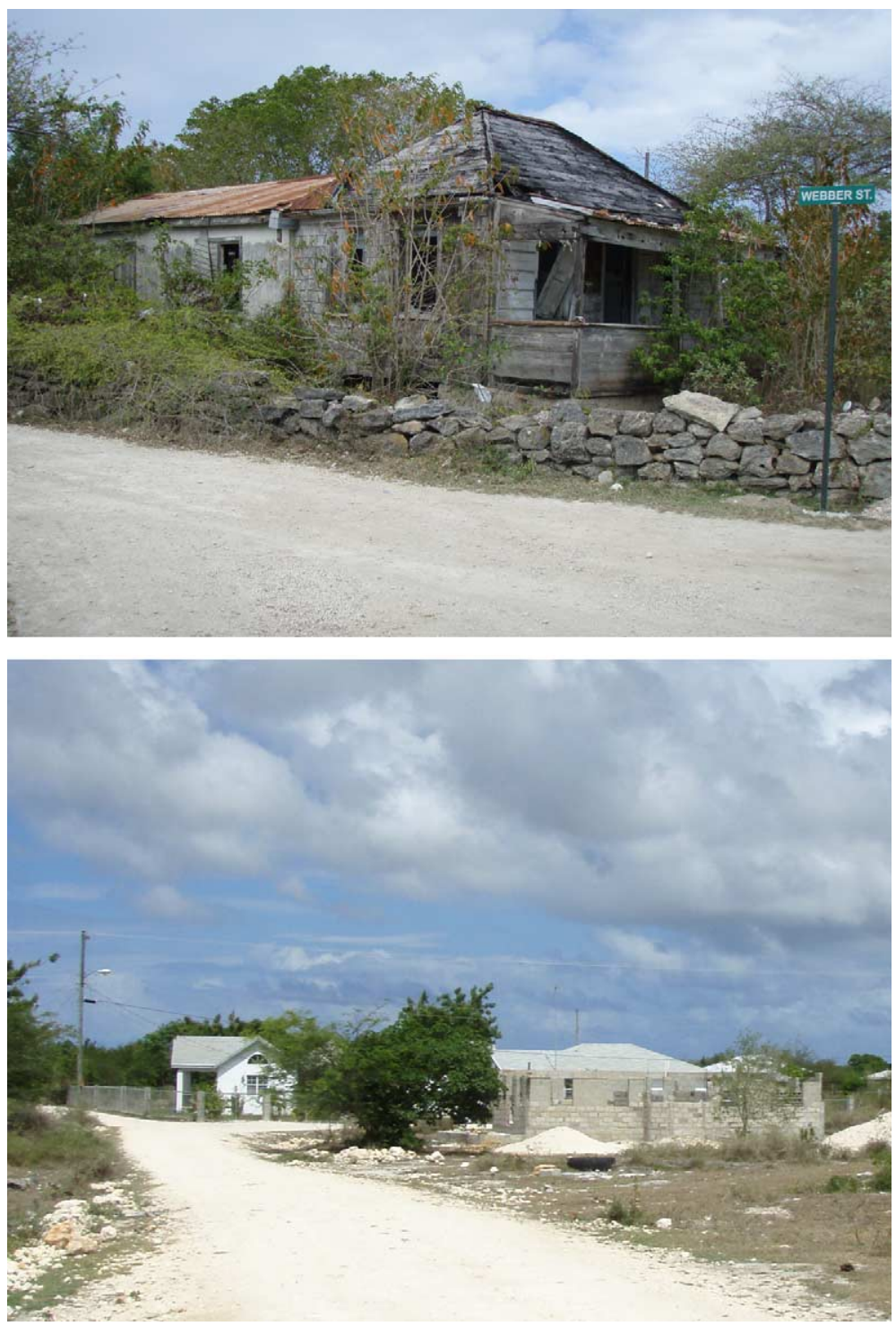

Figure 7. Top: abandoned colonial-era house at corner of Webber Street and Ginnery Street, located inside the former village wall. Bottom: recent residential construction east of the former village wall. Photography by Andrew Sluyter, June 2007.

Termination of Association Act, passed by the UK Parliament in 1981, in theory made all Crown lands into public lands administered by the new national government of independent Antigua and Barbuda (BerleantSchiller 1991). Yet many Barbudans argued that the island had become 
their communal property because soon after the end of the final lease the British Parliament had passed the Barbuda Ordinance of 1904 to make all Barbudans joint Crown tenants and, thereby, upon independence, joint owners (Lowenthal and Clarke 2007). That legal argument, along with traditional land use practices, served to frustrate the national government's efforts to establish unilateral control over Barbuda's land.

In part that legal argument sufficed because the land uses that prevailed during the late twentieth century required common access to unenclosed land. The wealthiest, most politically powerful Barbudans were the owners of the largest cattle herds and argued for communal land tenure to maintain their access to rangeland. But owners of small herds of cattle and goats, shifting cultivators, and charcoal burners would all have had good reason to argue for communal land tenure to protect their usufruct rights.

The national resource politics of the late twentieth century also gave Barbudans good reason to unite behind a legal argument for communal land tenure. With their majority, Antiguans control election of the national government, and the family of V. C. (Vere Cornwall) Bird controlled the government for most of the period of associated statehood and independence. The Birds enriched themselves by developing tourist resorts on public lands, to the social and environmental impoverishment of Antiguans (Coram 1993; Kincaid 1988). The uncertain status of land tenure on Barbuda limited such depredations there because investors could not raise capital to build resorts without clear title to land.

With the end of the Bird dynasty in 2004, Barbudans could begin to negotiate the formalization of their land-tenure system but at a time when the land uses that had mutually supported communal land tenure had become rare. The result has been The Barbuda Land Act, 2007, passed into law on 17 January 2008 after several years of negotiation among Barbudans and between the Barbuda Council and the national government (Antigua and Barbuda 2008). In general, the act codifies and enshrines Barbudans' communal ownership of their island, their usufruct rights, the inalienable status of the land, and the role of the Barbuda Council in administrating land use, including leasing land for any "major development for a maximum period of 50 years, or any longer period that the Council may, by regulation fix in accordance with this Act" (Antigua and Barbuda 2008, II-6).

The land act specifically addresses the issue of herding. Any Barbudan "of the age of 18 years and over shall, subject to availability, be entitled...to graze animals in areas of land in Barbuda designated by the Council for grazing" (Antigua and Barbuda 2008, III-7). The Agricultural, Land, and Fisheries Department of the Barbuda Council, plans to construct "paddocks" with wells to concentrate cattle. Those paddocks will become the areas "designated by the Council for grazing," and owners will pay a fee to water each head of cattle. 
Interviews, however, reveal the more typical purposes for which the Barbuda Council has been allocating land, purposes far different than the cattle herding that provided one of the principal historic foundations for the land act. The case of one middle-aged man illustrates how Barbudans now view tourism development rather than livestock or agriculture as key to their own and the island's future. He was born on Barbuda but moved with his family to the Virgin Islands soon thereafter as part of the Barbudan diaspora between World War II and associated statehood. After high school he moved to New York City, where he joined the expatriate Barbudan community focused in the Bronx and worked at various jobs before returning to Barbuda in 2004. Like other Barbudans who have returned from abroad with some capital, he has been at the forefront of acquiring approval from the council to develop land and now has rights to two plots: one near the south coast to build a home and construct tourist villas or apartments; and a second near the village jetty to build a gas station. In his view, "Barbuda is like a dirty diamond. It just needs to be polished." Other cases also reflect that conjunction of returning expatriates with capital and the new land act, such as the Barbudan who moved to Canada after high school and worked in light industry in the Toronto area for seventeen years before coming home and receiving approval to build a house and operate a restaurant on the south coast, not far from where the ferry from Antigua docks.

\section{Conclusions}

Historically, Barbudans seem to have persistently disregarded the legal status of land tenure in their actual land uses. During colonial times, the leaseholders and Colonial Office endlessly tried to confine Barbudans to Codrington, yet they nonetheless grazed their own livestock beyond the village wall, maintained shifting cultivation fields in the Highlands, and hunted deer. With associated statehood, despite the emergence of the legal argument for communal land tenure and usufruct rights for Barbudans only, not only the national government but the local one began to issue long-term leases to foreign developers of hotels and sand quarries. Now, just as Barbudans have largely abandoned land uses that supported the argument for usufruct rights to the entire island and begun to participate more broadly in ones that require investment capital, The Barbuda Land Act, 2007 has codified the inalienability of land and thereby precluded titling and the bank loans it would facilitate.

Conversely, open-range herding, as the most profitable land use for three centuries, had great impact on the eventual legal formalization of communal tenure. Yet, ironically, as the land act came into effect in 2008, the very landscape elements that manifest open-range herding have 
become obscure. Vegetation throughout the island certainly reflects three centuries of browsing, grazing, and burning associated with open-range herding, as well as shifting cultivation and charcoal production (Harris 1965). The rock-walled stockwells that persist in the environs of the village, however, provide a more obvious landscape legacy than the vegetation. Yet those wells have become largely defunct, many of the walls in ruins or entirely consumed by the rock crusher. Younger Barbudans, who grew up during the decline of cattle herding, barely appreciate that those wells even exist let alone how they once functioned as part of the open-range herding system that for so long characterized their island home. Older Barbudans do remember, and the council has undertaken to repair the wells as historic sites that can help preserve the social memory of place creation even as a very different Barbuda emerges over the next generation.

The historic tension between de jure land tenure and de facto land use implies that the recent passage of the land act will have little impact. Barbuda could well remain a regionally distinctive place, sparsely populated and little developed. But it could also become just another Small Place, much like the Antigua that Jamaica Kincaid (1988) bemoans: white beaches lined with mass tourism resorts, azure waters polluted with untreated sewage, and most of the development under foreign control and of minimal benefit to Barbudans. Or Barbudans might create one of many entirely different futures. They will be most empowered to do so, however, with a full appreciation for the complexity and uniqueness of the longterm processes that has thus far shaped their island.

\section{Acknowledgements}

Sincere thanks go to the many Barbudans for their patience with questions and other intrusions. Carina Giusti, Sophia A. Sluyter, and Nicole C. Sluyter assisted with fieldwork. The staffs of the National Archives of Antigua and Barbuda, the Museum of Antigua and Barbuda, the National Anthropological Archives (United States of America), and the National Archives (United Kingdom) located and reproduced archival materials. The American Geographical Society, Foreign Military Studies Office of the US Army, Robert C. West Field Research Award, LSU Data, Equipment, Lab Supplies Award, and the Association of American Geographers funded the research. Thanks go to Dr. David Harris and family for sharing Barbuda memories and photographs. Many thanks also to the anonymous reviewers who provided insightful feedback.

\section{Note}

1. Unless otherwise cited, the following information related to current cattle herding methods and other current island issues comes from interview notes and transcriptions from fieldwork conducted in June 2007 and June 2008. 


\section{References}

Albuquerque, K. de and McElroy, J., 1995. Antigua and Barbuda: a legacy of environmental degradation, policy failure and coastal decline. In: Supplementary Paper No. 5. Washington, DC: USAID, EPAT/MUCIA.

Antigua and Barbuda, 2008. The Barbuda Land Act, 2007. Official Gazette 28 (5): 1-18. Available at faolex.fao.org/docs/pdf/ant78070.pdf.

Barbuda. 2007. Codrington village road map, 1: 4,000. St. John's, Antigua: Sun Printing and Publishing.

Berleant-Schiller, R., Papers, Various Dates. Documents at the National Anthropological Archives, Smithsonian Institution, Washington, DC.

Berleant-Schiller, R., 1974. Subsistence and social organization in Barbuda, West Indies. Thesis (PhD). State University of New York at Stony Brook.

Berleant-Schiller, R., 1977a. Production and division of labor in a West Indian peasant community. American Ethnologist, 4, 253-72.

Berleant-Schiller, R., 1977b. The social and economic role of cattle in Barbuda. Geographical Review, 67, 299-309.

Berleant-Schiller, R., 1983. Grazing and gardens in Barbuda. In: R. BerleantSchiller and E. Shanklin, eds. The keeping of animals: adaptation and social relations in livestock producing communities. Totowa, New Jersey: Allanheld, Osmun and Company Publishers, 73-91.

Berleant-Schiller, R., 1984. Environment, technology, and the catch: fishing and lobster diving in Barbuda. In: B. Gunda, ed. The fishing cultures of the world. Budapest: Hungarian Academy of Sciences, 803-17.

Berleant-Schiller, R., 1986. Ecology and politics in Barbudan land tenure. In: J. Besson and J. Momsen, eds. Land and Development in the Caribbean. London: Macmillan, 116-131.

Berleant-Schiller, R., 1991. Hidden places and Creole forms: naming the Barbudan landscape. Professional Geographer, 43, 92-101.

Black, R., 1993. Migration, return, and agricultural development in the Serra do Alvao, Northern Portugal. Economic Development and Cultural Change, 41, 563-585.

Bromley, D.W., ed., 1992. Making the commons work: theory, practice, and policy. San Francisco: Institute for Contemporary Studies.

Byron, M., 2007. Collateral and achievement: land and Caribbean migration. In: J. Besson and J. Momsen, eds. Caribbean land and development revisited. New York: Palgrave Macmillan, 243-253.

Campbell, P., 2006. Barbuda sand mining proves difficult to manage. Antigua Sun, 24 October.

Coram, R., 1989. A reporter at large: Barbuda. The New Yorker, 76-94.

Coram, R., 1993. Caribbean time bomb: the United States' complicity in the corruption of Antigua. New York: William Morrow and Company.

Crosby, A.W., 1972. The Colombian Exchange: biological and cultural consequences of 1492. Westport, Connecticut: Greenwood Press.

DOS [Directorate of Overseas Surveys]. 1970. Barbuda topographic map, 1:25,000 and 1:10,000. Surbiton, Surrey, UK: DOS.

Durand, J. and Massey, D.S., 1992. Mexican migration to the United States: a critical review. Latin American Research Review, 27, 3-42. 
Feeny, D., Berkes, F., McCay, B.J., and Acheson, J.M., 1990. The tragedy of the commons twenty-two years later. Human Ecology, 18 (1), 1-18.

Francis, J., Rivera, C., and Figureroa, J., 1994. Towards a woody plant list for Antigua and Barbuda: past and present. New Orleans: Southern Forest Experiment Station, US Department of Agriculture.

Fuys, A., Mwangi, E., and Dohrn, S., 2005. Securing common property regimes in a 'modernizing' world: synthesis of 41 case studies on common property regimes from Asia, Africa, Europe and Latin America. Land Coalition 2005 [cited September 2008]. Available from: http://www.landcoalition.org/cd_ILC/cd_ commons/preface.html.

GEDG [Google Earth DigitalGlobe]. 2005. Satellite images from September 4, catalog numbers 10100100047F7801 and 10100100047F7802; September 9, catalog number 1010010004822205; October 28, catalog number 10100100049 D4001; December 3, catalog number 1010010004AF0802. http://earth.google. com.

Gmelch, G., 1992. Double passage: the lives of Caribbean migrants abroad and back home. Ann Arbor: University of Michigan Press.

Hall, D., 1971. Five of the Leewards 1834-1870: the major problems of the postemancipation period in Antigua, Barbuda, Montserrat, Nevis and St. Kitts. St. Laurence, Barbados: Caribbean Universities Press.

Hardin, G., 1968. The tragedy of the commons. Science, 162, 1243-48.

Hardin, G., 1998. Extensions of "the tragedy of the commons". Science, New Series, 280 (5364), 682-683.

Harris, D.R., 1965. Plants, animals, and man in the outer Leeward Islands, West Indies: an ecological study of Antigua, Barbuda, and Anguilla. Berkeley: University of California Press.

John, J., 1970a. Barbuda, goodbye? The Barbuda Voice, October, p. 8.

John, R., 1970b. The village well. The Barbuda Voice, October, p. 6.

John, R., 1970c. The Bradshaw interview in New York City. The Barbuda Voice, May, p. 9.

Jokish, B.D., 2002. Migration and agricultural change: the case of smallholder agriculture in highland Ecuador. Human Ecology, 30, 523-550.

Jordan, T., 1993. North American cattle ranching frontiers: origins, diffusion and differentiation. Albuquerque: University of New Mexico Press.

Kay, C., 1997. The ultimate tragedy of commons. Conservation Biology, 11 (6), 1447-1448.

Kincaid, J., 1988. A small place. New York: Farrar, Straus and Giroux.

Kishigami, N. and Savelle, J.M., eds., 2005. Indigenous use of management of marine resources (Senri Ethnological Studies no. 67). Osaka, Japan: National Museum of Ethnology.

Lawrence, M.B., 1996. Preliminary report, Hurricane Luis, 27 August11 September 1995. Miami, Florida: National Hurricane Center. Available at: www.nhc.noaa.gov/1995luis.html.

Lowenthal, D. and Clarke, C., 1977. Slave-breeding in Barbuda: the past of a Negro myth. Annals of the New York Academy of Sciences, 292, 510-35.

Lowenthal, D. and Clarke, C., 2007. Triumph of the commons: Barbuda belongs to all Barbudans together. In: J. Besson and J. Momsen, eds. Caribbean land and development revisited. New York: Palgrave Macmillan, 147-58. 
McCay, B. and Acheson, J., eds., 1987. The question of the commons: the culture and ecology of communal resources. Tucson, AZ: The University of Arizona Press.

Mills, B., 2007. "Leave to come back": the importance of family land in a transnational Caribbean community. In: J. Besson and J. Momsen, eds. Caribbean land and development revisited. New York: Palgrave Macmillan, 233-241.

Mutersbaugh, T., 2002. Migration, common property, and communal labor: cultural politics and agency in a Mexican village. Political Geography, 21, 473494.

Nicholson, D.V., 1991. Antigua, Barbuda, and Redonda: an historical sketch. St. John's, Antigua: Museum of Antigua and Barbuda.

Olwig, K.F., 1999. Caribbean place identity: from family land to region and beyond. Identities, 5, 435-67.

Perramond, E.P., 2008. The rise, fall, and reconfiguration of the Mexican ejido. Geographical Review, 98 (3), 356-371.

Punter, G., 1970. My views. The Barbuda Voice, October, p. 11.

Russell, R.J. and McIntire, W.G., 1966. Barbuda reconnaissance. Coastal Studies Series, no. 16. Baton Rouge: Louisiana State University Press.

Sauer, C.O., 1966. The early Spanish Main: the land, nature, and people Columbus encountered in the Americas. Berkeley: University of California Press.

SDMFE [Statistics Division of the Ministry of Finance and the Economy]. 2004. 2001 Census of population and housing, summary social, economic, demographic, and housing characteristics. St. John's, Antigua: SDMFE.

Sluyter, A., 2003. Material-conceptual landscape transformation and the emergence of the pristine myth in early colonial Mexico. In: K.S. Zimmerer and T.J. Bassett, eds. Political ecology: an integrative approach to geography and environment-development studies. New York: Guilford Press, 221-39.

Sluyter, A., 2009. The role of black Barbudans in the establishment of open-range cattle herding in the colonial Caribbean and South Carolina. Journal of Historical Geography, 35, 330-349.

Sserunkuuma, D. and Olson, K., 2001. Private property rights and overgrazing: an empirical assessment of pastoralists in Nyabushozi County, Western Uganda. Economic Development and Cultural Change, 49 (4), 769-92.

Tweedy, M.T., 1981. A history of Barbuda under the Codringtons, 1738-1833. Thesis. University of Birmingham, UK.

USAF [US Air Force]. 1958. Aerial photographs of 4 February, focal length 0.5 feet, nominal altitude 12,000 feet, nominal scale 1:24,000.

Verdery, K., 2003. The vanishing hectare: property and value in postsocialist Transylvania. Ithaca, New York: Cornell University Press.

Watters, D.R., 1980. Observations on the historic sites and archaeology of Barbuda. Journal of Archaeology and Anthropology, 3, 125-54.

Watts, D., 1987. The West Indies: patterns of development, culture and environmental change since 1492. Cambridge: University of Cambridge Press. 